\title{
Biochemical methane potential assays to test the biogas production from the anaerobic digestion of sewage sludge and other organic matrices
}

\author{
C. Morosini ${ }^{1}$, F. Conti ${ }^{1}$, V. Torretta ${ }^{1}$, E. C. $\operatorname{Rada}^{2}$, G. Passamani ${ }^{1}$, \\ M. Schiavon ${ }^{2}$, L. I. Cioca ${ }^{3} \&$ M. Ragazzi ${ }^{2}$ \\ ${ }^{1}$ University of Insubria, Italy \\ ${ }^{2}$ University of Trento, Italy \\ ${ }^{3}$ Lucian Blaga University of Sibiu, Romania
}

\begin{abstract}
The present paper shows the results of some anaerobic digestion batch assays carried out with the objective to test the biochemical methane potential of a sewage sludge taken from a wastewater treatment plant in Varese (Northern Italy). In order to optimize the waste treatment and consequently to increase the energetic yield of the process, some biological and chemical pre-treatments were applied to enhance the hydrolytic step. These pre-treatments mainly consisted of adding external enzymes or a nutrient solution able to create the optimal conditions for the reaction start-up. In addition, different organic matrices were added to sewage sludge with the aim of testing the benefits achievable by using co-digestion.

The method used to check the biochemical methane potential was based on a volumetric test, which converted the displacement of a liquid barrier into the measure of biogas production. In order to do so, each assay was developed by using three different positions running in parallel.

Keywords: biochemical methane potential, anaerobic digestion and co-digestion, sewage sludge, organic matrices, biogas production.
\end{abstract}

\section{Introduction}

The minimization of sewage sludge is an issue of great concern since its disposal represents one of the major operating costs of a wastewater treatment plant. At the 
same time, the disposal route has to be environmentally sustainable and compatible with law provisions. Anaerobic digestion plays an important role in achieving both the two goals, since it contributes to further transform organic matter into biogas, thus reducing the total amount of solids to be disposed, to remove a large part of the pathogens and to control the air dispersion of odour nuisance $[1,2]$.

The anaerobic process is a technical solution studied for many years considering different aspects, both the technical and the economic ones. The process converts a large part of COD into biogas (composed by methane) or biohydrogen thanks to its high removal efficiency. The starting point for obtaining a good removal of the organic substance during the anaerobic digestion (AD), is to properly select the technical solution and the biomass to be fed to the anaerobic system [3-7].

Biogas has been widely recognized for long as a renewable energy source and current research efforts are addressed towards finding new technological solutions able to improve its quality, thus enhancing its energy use. In order to achieve this goal, different pre-treatments, mainly applied to accelerate the hydrolysis phase, which often represents the limiting step of the anaerobic digestion process, can be implemented, among which mechanical, biological, chemical and thermal interventions. They all aim at solubilizing intracellular material and converting the biorefractory substances into more biodegradable species through the mechanism of cells lysis [1].

In order to assess the anaerobic biodegradation potential of a substrate, different experimental tests can be carried out, among which one of the less expensive and easier to set up is the bio-methane potential test (BMP). The BMP test runs in anaerobic batch conditions and allows to measure the maximum amount of biogas or bio-methane produced per gram of volatile solids: the gas produced by an organic substrate mixed with an anaerobic inoculum, under defined operational conditions, is quantified by using a specific measurement method [8]. The two most common methods are the manometric and the volumetric methods. The one used in this paper is the volumetric method, which is based on the determination of the biogas produced when pressure and temperature are kept constant. In particular, the equipment (based on Eudiometer or a graduated reverse cylinder filled with a barrier solution) converts the displacement of a liquid into the measurement of $\mathrm{CH}_{4}$, since $\mathrm{CO}_{2}$ is removed from biogas by bubbling it through a $\mathrm{NaCl} 6 \mathrm{M}$ solution [9].

The present paper shows the results of some anaerobic digestion batch assays (BMP tests) carried out with the objective to test the biochemical methane potential of a sewage sludge taken from a wastewater treatment plant in Varese (Northern Italy). These tests were conducted using both a pure substrate (the sewage sludge of the plant), by adding external enzymes or a nutrient solution (to enhance the hydrolytic step), and a mixture of different organic wastes, in order to assess the effect of co-digestion on the bio-methane yield of the process. 


\section{Materials and methods}

In this paper, the results of some BMP assays are shown: they all refer to the experimental equipment described below since, after some tests carried out in the past, using a different type of instrumentation, the authors agreed that the one here presented is the most suitable. It is based on the Eudiometer, a volumetric method which uses the liquid displacement to measure the biogas produced. In particular, the method allows to measure the $\mathrm{CH}_{4}$ produced after removing $\mathrm{CO}_{2}$ from biogas by bubbling it through a barrier solution, which is, in this case, a $\mathrm{NaCl}$ $6 \mathrm{M}$ solution.

Each BMP test was performed in triplicate by using three $2000 \mathrm{~mL}$ glass bottles (Woulff bottles). Each bottle was filled with $1000 \mathrm{~mL}$ of fresh sludge (a mixture of primary and biological sludge taken from a full scale wastewater treatment plant in Varese, Northern Italy), $24 \mathrm{~g}$ of inoculum (anaerobic sludge taken from the digester of the plant) and, depending on the test, with external enzymes, a nutrient solution or a different organic substrate to test the efficacy of co-digestion. All bottles were stirred, for the whole duration of the test (about 20 days, on average), by a magnetic stirrer and they were immersed in hot water kept at a constant temperature of about $35^{\circ} \mathrm{C}$ (mesophilic conditions) by a submersible heater. Each bottle was connected to a $2000 \mathrm{~mL}$ glass graduated eudiometer, $80 \mathrm{~mm}$ diameter, filled with a $\mathrm{NaCl} 6 \mathrm{M}$ methylene blue coloured barrier solution, able to remove $\mathrm{CO}_{2}$, once a day fixed at an established level. Inside each eudiometer, a capillary tube conveys the biogas produced to the head space. Once accumulated here, the biogas forces the barrier solution into a lateral tube connected with another bottle (Mariotte bottle, one for each eudiometer position) at a higher level: the liquid displacement in the eudiometer is then converted into $\mathrm{mL}$ of $\mathrm{CH}_{4}$ developed. The experimental equipment is shown in Figure 1.

At the beginning and at the end of each test, pH, TS, VS, COD, VFA and alkalinity were measured according to [10-13]. As a nutrient solution, to enhance the biomass growth, was used the following one: $\mathrm{K}_{2} \mathrm{HPO}_{4}, 2 \mathrm{mM} ; \mathrm{FeCl}_{3} 6 \mathrm{H}_{2} \mathrm{O}$, $0.1 \mathrm{mM} ; \mathrm{NaHCO}_{3}, 10 \mathrm{mM} ; \mathrm{CaCl}_{2}$ (anhydrous), $0.51 \mathrm{mM} ; \mathrm{MgSO}_{4} 7 \mathrm{H}_{2} \mathrm{O}, 0.50$ $\mathrm{mM}$ (in one liter distilled water, $10 \mathrm{~mL}$ for each bottle). To enhance the hydrolytic step, some external enzymes (purchased from Eurovix) were added ( $1 \mathrm{~g}$ for each bottle).

For the co-digestion tests, three different organic substrates were used ( $20 \mathrm{~g}$ for each bottle): cattle manure (taken from a farm in the surroundings of Varese and homogenized before using it), beer waste (non pre-treated waste deriving from a beer factory in Varese) and algae (taken from the Lake of Varese by using a $40 \mu$ mesh sieve and centrifuged before use). Each substrate was added to the blank sample, represented by fresh sewage sludge plus inoculum. The main characteristics of the blank sample and the three organic substrates, in terms of VS and COD, are shown in Table 1. 


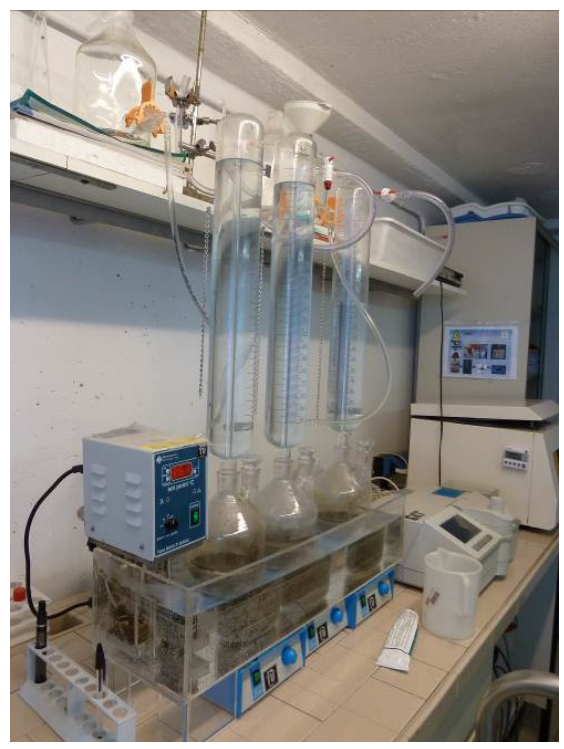

Figure 1: The experimental equipment used for BMP assays.

Table 1: Main characteristics of the blank sample and the three organic substrates tested, in terms of VS and COD.

\begin{tabular}{|c|c|c|}
\hline Substrate & VS [mg/L] & COD [mg/L] \\
\hline Blank sample & $13934-28102^{*}$ & $22940-39905^{*}$ \\
\hline Cattle manure & 23163 & 35615 \\
\hline Beer waste & 21946 & 36745 \\
\hline Algae & 19091 & 34540 \\
\hline
\end{tabular}

*Variability range of VS and COD for blank sample in all the tests.

In total, five BMP tests were conducted. The structure and the composition of each BMP test are shown in Table 2.

Table 2: Composition of each BMP test.

\begin{tabular}{|c|c|c|c|c|c|}
\hline & BMP test 1 & BMP test 2 & BMP test 3 & BMP test 4 & BMP test 5 \\
\hline Bottle 1 & $\begin{array}{c}\text { Blank } \\
\text { sample }\end{array}$ & $\begin{array}{c}\text { Blank } \\
\text { sample } \\
\end{array}$ & $\begin{array}{c}\text { Blank } \\
\text { sample }\end{array}$ & $\begin{array}{c}\text { Blank } \\
\text { sample }\end{array}$ & $\begin{array}{c}\text { Blank } \\
\text { sample }\end{array}$ \\
\hline Bottle 2 & $\begin{array}{c}\text { Blank } \\
\text { sample }\end{array}$ & $\begin{array}{c}\text { Blank } \\
\text { sample }+ \\
\text { External } \\
\text { enzymes }\end{array}$ & $\begin{array}{c}\text { Blank } \\
\text { sample + } \\
\text { Nutrient } \\
\text { solution } \\
\end{array}$ & $\begin{array}{c}\text { Blank } \\
\text { sample }+ \\
\text { Cattle } \\
\text { manure } \\
\end{array}$ & $\begin{array}{l}\text { Blank } \\
\text { sample + } \\
\text { Algae }\end{array}$ \\
\hline Bottle 3 & $\begin{array}{c}\text { Blank } \\
\text { sample }\end{array}$ & $\begin{array}{c}\text { Blank } \\
\text { sample + } \\
\text { External } \\
\text { enzymes }\end{array}$ & $\begin{array}{c}\text { Blank } \\
\text { sample }+ \\
\text { Nutrient } \\
\text { solution }\end{array}$ & $\begin{array}{c}\text { Blank } \\
\text { sample + } \\
\text { Beer waste }\end{array}$ & -* \\
\hline
\end{tabular}

*In the BMP test 5, just two bottles were used due to the small amount of algae available. 


\section{Results}

In Figure 2, a comparison among the six different scenarios tested during the five BMP tests above mentioned, in terms of COD and VS removal, is shown.

In the case of a blank sample, a mean of the removal percentages (seven as a whole) obtained in each BMP test was considered, since it was tested in more than one bottle (BMP test 1) and in all the BMP assays. These percentages varied in the range $30 \%-59 \%$ (as regards COD) and 25\%-43\% (as regards VS).

In the case of external enzymes and nutrient solution, a mean of the two removal percentages (two bottles tested per each scenario) obtained in BMP tests 2 and 3 , respectively, was considered.

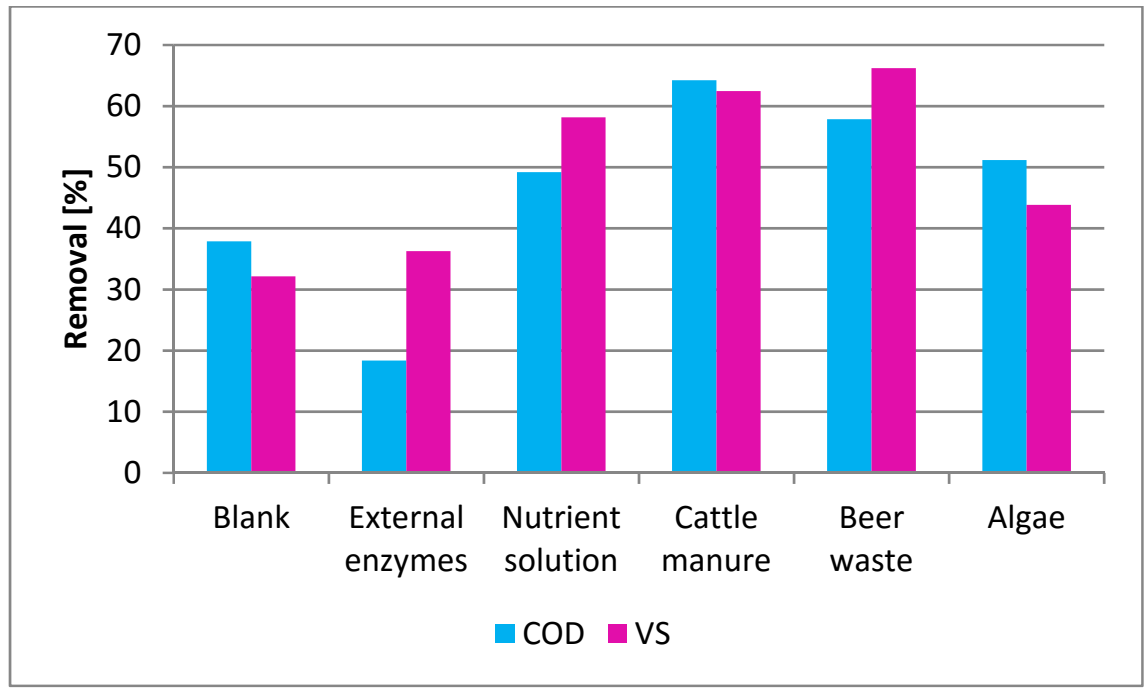

Figure 2: COD and VS removal (\%) during the BMP tests: comparison among six different scenarios.

In general, as regards the different conditions initially applied for enhancing the hydrolytic phase, the addition of a nutrient solution appears as the best solution in terms of both COD and VS removal, compared to the blank sample and the addition of external enzymes. As regards the co-digestion assays, the addition of both cattle manure and beer waste as co-substrates appears as a good solution to improve the performance of the digestion process.

In order to better understand the behaviour of the different organic matrices and the different conditions tested in terms of bio-methane production yield, a balance of the cumulative volume $(\mathrm{mL})$ of $\mathrm{CH}_{4}$ produced was made by evaluating the liquid displacement within the eudiometric tube connected with each bottle. As before, in case of blank sample, external enzymes and nutrient solution, a mean of 
the $\mathrm{CH}_{4}$ produced in different bottles of the same test and, for blank sample only $\left(\mathrm{CH}_{4}\right.$ in the range $\left.1760 \mathrm{~mL}-5880 \mathrm{~mL}\right)$, also in different BMP assays, was considered. The results are shown in Figure 3.

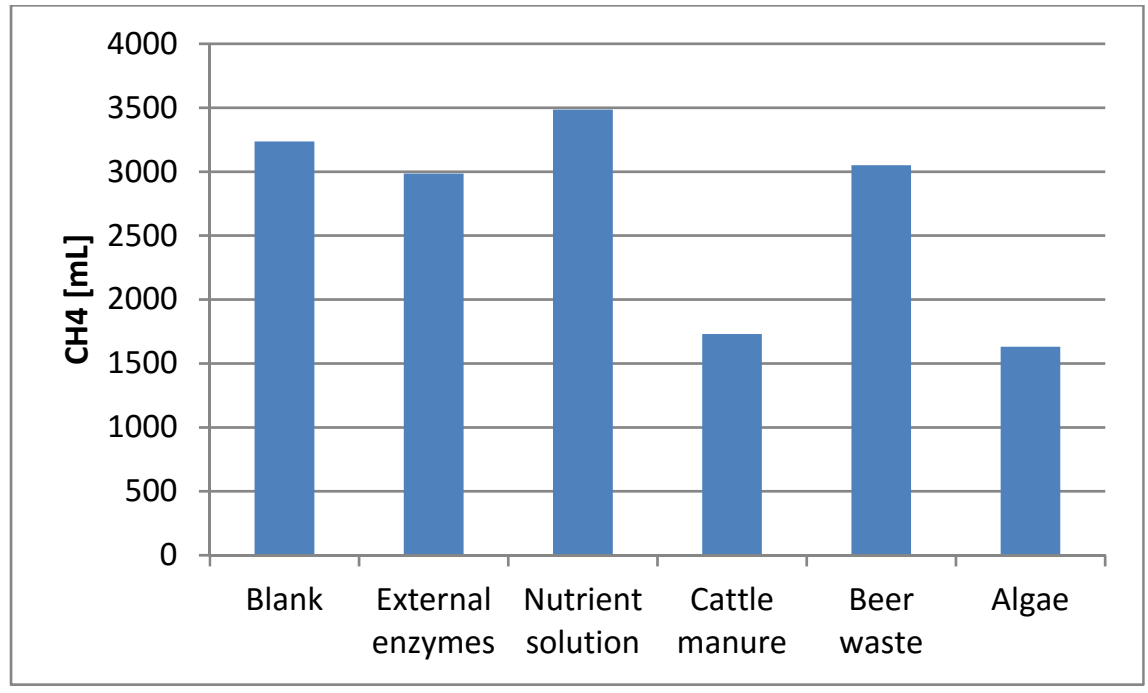

Figure 3: Cumulative $\mathrm{CH}_{4}$ production in six different scenarios.

The bars in Figure 3 show that there is not a perfect correspondence between the COD and VS removals, reported in Figure 2, and the final $\mathrm{CH}_{4}$ production observed in the same BMP test. This is probably due to some gas losses occurred during BMP tests 4 and 5 (co-digestion assays). In fact, as reported in [14], a COD balance can be verified by comparing the COD of the substrate present in the reactor at the beginning of the test to the sum of the $\mathrm{COD}$ of the final digestate and the COD of methane $\left(2.86 \mathrm{~g} \mathrm{COD} / \mathrm{L} \mathrm{CH}_{4}\right)$. The first member of this simple equation cannot differ by more than $10-15 \%$ from the second one, otherwise some analytical errors were probably made or, in case the second member should be much lower than the first one, it is plausible to think that some gas losses occurred during the test. This is exactly what occurred during the co-digestion assays.

In order to have a direct comparison among the five BMP tests, in terms of $\mathrm{CH}_{4}$ obtained, Figure 4 shows the trend of all the methane production cumulative curves derived from the digestion process which occurred in each bottle.

In particular, as shown in Figure 4d), the BMP test referred to the third bottle (blank sample plus beer waste) started later than the others since some hydraulic problems occurred and this fact could probably explain why the final methane production was lower than expected. 
a)

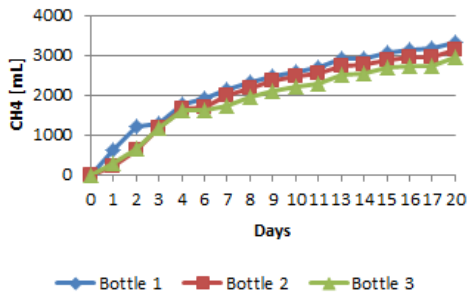

c)

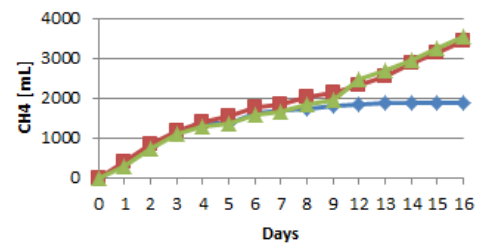

$\longrightarrow$ Bottle $1-$ Bottle $2 \multimap$ Bottle 3 b)

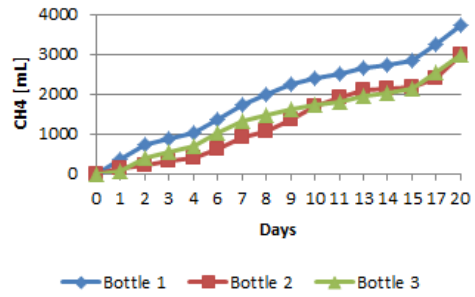

d)

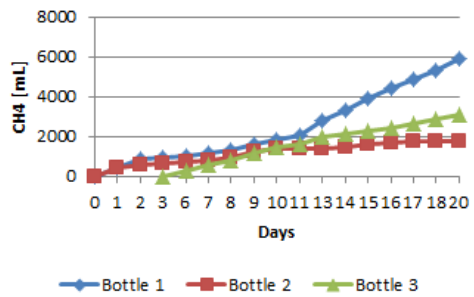

e)

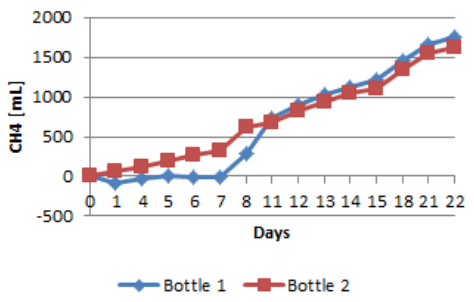

Figure 4: Methane production cumulative curves: a) BMP test 1; b) BMP test 2 ; c) BMP test 3; d) BMP test 4; e) BMP test 5.

\section{Conclusions and outlooks}

The results of the BMP assays, carried out in the present work, seem to show that the addition of a nutrient solution to a sample of sewage sludge, inoculated with an anaerobic biomass withdrawn from a full scale digester, can improve the performance of the digestion process, both in terms of COD and VS removal and in terms of methane production. This is probably due to an improvement of the environment where microorganisms live, which becomes more favourable to their growth and their biodegradation activity. As regards the co-digestion assays, the addition of other organic substrates to the sample of sewage sludge appears as an interesting solution to enhance the digestion process in terms of COD and VS removal, especially if the organic matrix is undergone an initial pre-treatment, when needed. This could be the case of cattle manure, whose size has to be reduced in order to be more soluble and hence not to slow down the hydrolytic phase, 
which is generally the limiting step of the whole process. Even if the addition of other organic substrates improved the general performance of the digestion process, this result apparently did not match with the energetic yield obtained during the corresponding BMP tests, where the final methane production proved to be lower than expected. This unsatisfactory result might be due to some gas losses occurred during the test, hypothesis which seems to find a confirmation in the evaluation of the COD balance. As regards the use of algae as a co-substrate, other detailed studies have to be carried out in order to better understand their biomethane potential which, if demonstrated, might be a promising tool to increase the energetic yield of the process and, at the same time, to find a sustainable solution to the eutrophication problem of the Lake of Varese. Other efforts have to be made in the next future to minimize those errors which are related to the instrumentation and to standardize the protocol for the implementation of the BMP tests. A better characterization of the initial inoculum added to sewage sludge has to be made as well. Finally, the presented approach is surely interesting in contexts where a full scale anaerobic digester for sewage sludge is already working and there is a local interest to improve the biogas generation to support, for instance, a sludge thermal drying aimed to decrease the mass to be transported to an external final user (e.g. a cement factory). Of course, all the strategies of co-digestion must be checked in terms of additional generation and release of pollutants from the exploitation of the extra amount of biogas.

\section{Acknowledgement}

The authors thank Prealpi Servizi S.r.l. for the support provided during the batch experiences.

\section{References}

[1] Appels, L., Baeyens, J., Degrève, J., Dewil, R., Principles and potential of the anaerobic digestion of waste-activated sludge. Progress in Energy and Combustion Science 34, pp. 755-781, 2008.

[2] Ferrentino, R., Langone, M., Andreottola, G., Rada, E.C., An anaerobic side-stream reactor in wastewater treatment: A review, WIT Transactions on Ecology and the Environment, 191, pp. 1435-1446, 2014.

[3] Fehrenbach, H., Giegrich, J., Reinhardt, G., Sayer, U., Gretz, M., Lanje, K., Schmitz, J., Kriterien einer nachhaltigen Bioenergienutzung im globalen Maßstab (Criteria for sustainable bioenergy use on a global scale). UBAForschungsbericht, 206, pp. 41-112, 2008.

[4] Buendía, I.M., Fernández, F.J., Villaseñor, J., Rodríguez, L., Feasibility of anaerobic co-digestion as a treatment option of meat industry wastes. Bioresource Technol., 100, pp. 1903-1909, 2009.

[5] Torretta, V., Conti, F., Leonardi, M., Ruggeri, G., Energy recovery from sludge and sustainable development: a Tanzanian case study. Sustainability, 4, pp. 2661-2672, 2012. 
[6] Callegari, A., Torretta, V., Capodaglio, A.G., Preliminary trial application of biological desulfonation in anaerobic digestors from pig farms. Environ. Eng. Manage. J., 12(4), pp. 815-819, 2013.

[7] Rada, E.C., Ragazzi, M., Torretta, V., Laboratory-scale anaerobic sequencing batch reactor for treatment of stillage from fruit distillation. Water Sci. Technol., 67(5), 2013.

[8] Martinez, S.L., Torretta, V., Vázquez Minguela, J., Siñeriz, F., Raboni, M., Copelli, S., Rada, E.C., Ragazzi, M., Treatment of effluents from slaughterhouses using anaerobic filters. Environ. Technol. 35(3), pp. 322332, 2014.

[9] Esposito, G., Frunzo, L., Liotta, F., Panico, A., Pirozzi, F., Bio-Methane Potential Tests to Measure the Biogas Production from the Digestion and Co-Digestion of Complex Organic Substrates. The Open Environmental Engineering Journal 5, pp. 1-8, 2012.

[10] Müller, W-R., Frommert, I., Jörg, R., Standardized methods for anaerobic biodegradability testing. Reviews in Environmental Science and Bio/Technology 3, pp. 141-158, 2004.

[11] Manuali e Linee Guida APAT IRSA CNR Volume 1, Sezione 2000, 29/2003.

[12] IRSA-CNR, Quaderni, $N^{\circ} 64,1983-85$. Metodi analitici per i fanghi.

[13] Kit Lange LCK $36550-2500 \mathrm{mg} / \mathrm{l}$ as acetic acid (internal method).

[14] APHA/AWWA/WEF, Standards Methods for the Examination of Water and Wastewater, 20th ed., United Book Press, Inc., Baltimore, Maryland, 1998.

[15] Ficara, E., Malpei, F., Martinucci, E., Porqueddu, I., La misura della degradabilità anaerobica. Available at: http://www.fabbricabioenergia. polimi.it/index.php?option $=$ com_content\&view $=$ article\&id $=69 \&$ Itemid $=5$ \&lang=it 